\title{
Energy efficiency evaluation of an innovative vertical axial rotary kiln for pottery production
}

\section{Evaluación de la eficiencia energética de un horno rotatorio axial vertical para la producción de cerámica}

\section{Carlos Andrés Forero Núñez}

Chemical Engineer, Ph.D Engineering-Materials Science and Technology. Assistant Professor. Department of Mechanical and Mechatronics Engineering, Universidad Nacional de Colombia. Bogotá, Colombia. Contacto: caforeron@unal.edu.co

\section{Germán Arturo López Martínez}

Mechanical Engineer, Technology Teaching Specialist, MSc Mechanical Engineering. Associate Professor. Technology Faculty. Universidad Distrital "Francisco José de Caldas”. Bogotá, Colombia. Contacto: galopezm@udistrital.edu.co

\section{Fabio Emiro Sierra Vargas}

Mechanical Engineer, MSc Industrial Automatization, Dr.-Ing in Engineering. Associate Professor. Department of Mechanical and Mechatronics Engineering. Universidad Nacional de Colombia. Bogotá, Colombia.

Contacto: fesierrav@unal.edu.co

Fecha de recepción: 21 de febrero del 2014

Clasificación del artículo: investigación

Fecha de aceptación: 15 de agosto del 2014

Financiamiento: Colciencias, Project No. 1101-521-29311

DOI: http://dx.doi.org/10.14483/udistrital.jour.tecnura.2015.1.a07

Keywords: combustion, energy efficiency, pottery, rotary kiln.

Palabras clave: alfarería, combustión, eficiencia energética, horno rotatorio.

\section{ABSTRACT}

Colombia is a remarkable coal producer and exporter worldwide; several sectors use this resource for electricity and thermal energy production. Among them, the ceramic industry consumed 118,590 tons in 2011. Most of the pottery production companies in this country are located in rural areas and use old coal fired kilns with low energy efficiencies, generating environmental effects to the population nearby. Despite of the importance of these industries to the small rural economies, the government agencies have closed them due to the lack of development on cleaner devices. This work aims to analyze the thermal behavior of an innovative vertical axial rotary kiln 
for pottery production, and the energy efficiency varying operation mode. The kiln, operated during seven hours, needed three hours for stabilizing the sintering temperature at $800^{\circ} \mathrm{C}$. The mean temperatures of the loading, drying, sintering and cooling stage were $204^{\circ} \mathrm{C}, 223^{\circ} \mathrm{C}, 809^{\circ} \mathrm{C}$ and $321^{\circ} \mathrm{C}$ respectively. The convection and radiation heat losses were $15 \%$ whereas the flue gas heat losses $18 \%$.During continuous operation, the kiln energy efficiency was about $60 \%$. This design proven to reach the temperatures required in the firing stage of the pottery production; moreover, a gas fuel was fuelled making the process cleaner and more efficient than coal-fired systems.

\section{RESUMEN}

Colombia es un importante productor y exportador de carbón a nivel mundial. Múltiples sectores utilizan este recurso para la producción de energía térmica y eléctrica, entre los cuales se encuentra la industria cerámica, que en el 2011 tuvo un consumo de 118590 toneladas. La mayor parte de las industrias de alfarería se encuentran en áreas rurales y utilizan hornos antiguos alimentados con carbón con baja eficiencia energética, generando efectos ambientales considerables a la población circundante. A pesar de la importancia de estas industrias para las pequeñas economías rurales, agencias nacionales gubernamentales han cerrado varias debido a la falta de desarrollo de sistemas más limpios. Este trabajo pretende analizar el comportamiento térmico de un horno rotatorio de eje vertical para la alfarería y su eficiencia energética variando el modo de operación. El horno operó durante siete horas y necesitó tres horas para alcanzar $800^{\circ} \mathrm{C}$ en la cámara de sintetización o cocido. Las temperaturas promedio de las cámaras de carga, secado, cocido y enfriamiento, a partir del momento de estabilización fueron 204, 223, 809 y $321^{\circ} \mathrm{C}$ respectivamente. Las pérdidas por radiación y convección al ambiente fueron equivalentes al 15\%, mientras que las pérdidas relacionadas con los gases de combustión fueron del 18\%. Durante la operación en continuo la eficiencia energética del sistema alcanza el 60\%. Este diseño innovador demostró alcanzar las temperaturas requeridas en el proceso de alfarería; más aún permitió el uso de un combustible gaseoso, haciendo el proceso más limpio y eficiente que los sistemas tradicionales alimentados por carbón.

\section{INTRODUCTION}

Energy is fundamental for the society. The world primary source of energy increases every year at higher rates. Based on the statistics presented by the International Energy Agency (International Energy Agency (IEA), 2012), while the energy reached 10000 Mtoe at a rate of 145 Mtoe/year between 1970 and 2000, in the last decade that rate was 200 Mtoe/year and the energy supply was 12000 Mtoe. The expansion of the coal share caused that phenomena; this fossil fuel has become more valuable due to the higher prices of other fossil fuels such as natural gas and oil fuel middle distillates. The coal production is increas-

ing faster than over the past decades. In the 90 's, the average production was about $4500 \mathrm{Mt}$ while, in 2011, it was $8000 \mathrm{Mt}$. The proven coal reserves in Colombia are $6508 \mathrm{Mt}$ and they are distributed along the three sections of the Andes (UPME, 2012). The large difference between the production and the consumption of coal makes Colombia the fifth most prominent exporter worldwide, after Indonesia, Australia, Russia and the United States (International Energy Agency (IEA), 2012). This fuel is the second most indispensable resource for electricity generation, and the main source for primary energy in this country. The distribution of the coal consumption by sector is wide; coal is valuable for industries such as the 


\section{investigación}

electrical, charcoal, textile, steel, food, tobacco, paper, cement and ceramics. The use of fired coal systems results on a lot of environmental effects and pollutants such as $\mathrm{CO}_{2}, \mathrm{NO}_{x}, \mathrm{SO}_{x}$, and particulate matter. In 2010, coal combustion produced $43 \%$ of the $\mathrm{CO}_{2}$ emissions; it increased $4.9 \%$ and represented $13.1 \mathrm{GtCO}_{2}$ (International Energy Agency (IEA), 2011). Hence, several studies about coal science were carried out to identify cleaner processes for coal combustion such as liquefaction (Matheus, Miller, Song, Schobert, Botha, \& Finkleman, 2013), integrated gasification combined cycles (IGCC) (Zhang, Zhou, Ma, Li, \& Ni, 2013), biomass co-firing systems (Jones, Bridgeman, Darvell, Grudka, Saddawi, \& Williams, 2012) and sulfur removal techniques (Cheng, y otros, 2003).

In Colombia, the ceramic industry consumed about 118590 tons of coal in 2011. An important share of this demand came from the pottery production companies. This process implies the clay extraction, clay pretreatment, samples shaping and firing (Artesanias de Colombia S.A., 2008). Raquira is a small town located at $5,538^{\circ} \mathrm{N}$, $-73,363^{\circ} \mathrm{W}$ and $2,120 \mathrm{~m}$ above the average sea level, where more than 50 coal mines are located nearby, and 350 small and medium scale firing kilns exist (Sinning Durán, 2010), consuming approximately 4,800 tons coal annually. These kilns are operated by batch cycles typically; they are warmed up until reaching a sintering temperature between 800 and $1000^{\circ} \mathrm{C}$. The equipment maintains that temperature for two to four hours before cooling down. The kilns installed in Raquira are extremely old with no control of the outlet gas temperature and inappropriate insulation, resulting on low energy efficiencies and several greenhouse gases (GHGs). Some national agencies have established severe policies to decrease the impact of these industries; the city council has determined that these kilns have no technical improvements closing most of them, affecting the employment of almost 11000 inhabitants
(Concejo Municipal de Ráquira, 2012). After making a review of the different studies regarding pottery production processes, we found that they mainly focus on the kilns employed on the cement industry and the pottery chemical characterization (Trindade, Dias, Rocha, Prudencio, \& Coroado, 2011) (Rasmussen, De la Fuente, Bond, Mathiesen, \& Vera, 2012) (Matau, Nica, Postolache, Ursachi, Cortiug, \& Stancu, 2013). However, the analysis of the thermal behavior and the energy efficiency is a remarkable factor to consider. Marias (Marias, 2003) presented a new development in the study of a rotary kiln incinerator using the possible coupling between gPROMS ${ }^{\mathrm{TM}}$ and Fluent ${ }^{\mathrm{TM}}$. Ginsberg and Modigel (Ginsberg \& Modigell, 2011) established a rigorous onedimensional dynamic model of a rotary kiln for calcination of titanium dioxide white pigment; they considered the heat losses from the kiln outer shell to the environment, and determined useful equations for calculating the convection and radiation heat losses. Sogut et al. (Sogut, Oktay, \& Karakoc, 2010) performed a complete thermal analysis of a rotary kiln for the cement industry and stated that the energy efficiency of that equipment was $61 \%$; moreover, they indicated that $5 \%$ of the waste heat can be utilized with a recovery exchanger. A fundamental issue is that the energy efficiency depends upon the design of the equipment; therefore, it might be determined on each process. According to Saidur et al, the process industries must introduce a variety of energy savings measurements and energy recycling systems to achieve the highest levels of energy efficiency (Saidur, Hossain, Islam, Fayaz, \& Mohammed, 2011). The redesign of these systems has not been implemented in developing countries despite their vast needs to save energy as well as to control their industrial pollution. Some alternatives can be performed in order to decrease the environmental problems associated with fossil fuel combustion. According to Olajire (Olajire, 2010), they are (1) reducing energy intensity; (2) reducing carbon intensity, i.e, use of carbon-free 
fuel; and (3) enhancing the sequestration of $\mathrm{CO}_{2}$. This study aims to analyze the thermal behavior of an innovative vertical axial rotary kiln for pottery production fuelled with a cleaner gas fuel, and the variation of the energy efficiency due to continuous operation.

\section{METHODOLOGY}

\section{Vertical rotary kiln}

The detailed layout of the kiln is illustrated in figure 1 . The vertical rotatory kiln contained some fixed pieces; two chimneys welded to the cover (1) take out the flue gases from the drying and cooling stages. This cover was installed over an aluminum rounded external plate (6), where the burners (5) were mounted; meanwhile, this plate was supported by a steel basis (13). The aluminum plate enclosed the heat insulator (4), mainly white glaze fiber, and the external wall of the chambers
(3). These were made of refractory bricks, as well as the internal walls (2); two horizontal metallic layers were installed to place the pottery samples inside the chambers. Some holes were made at the middle of the internal walls to promote the diffusion of the flue gases from the sintering to the cooling and the drying stages. The internal walls were mounted over a circular plate (7) fixed to the bearing system (8-12) making possible the rotation of the chambers inside the kiln.

\section{Experimental test setup}

The tests were performed at the laboratory of Thermal Plants and Renewable Energy, Bogotá Colombia $\left(4,638^{\circ} \mathrm{N}-74,084^{\circ} \mathrm{W}, 2,630 \mathrm{~m}\right.$ above mean sea level). The fuel used was propane and a gas flowmeter JB2-M measured the fuel consumption. It was installed between the gas tank and the burners. Fuel flow rate was controlled by regulating the outlet pressure of the gas, but an on-off valve was installed to prevent any ac-

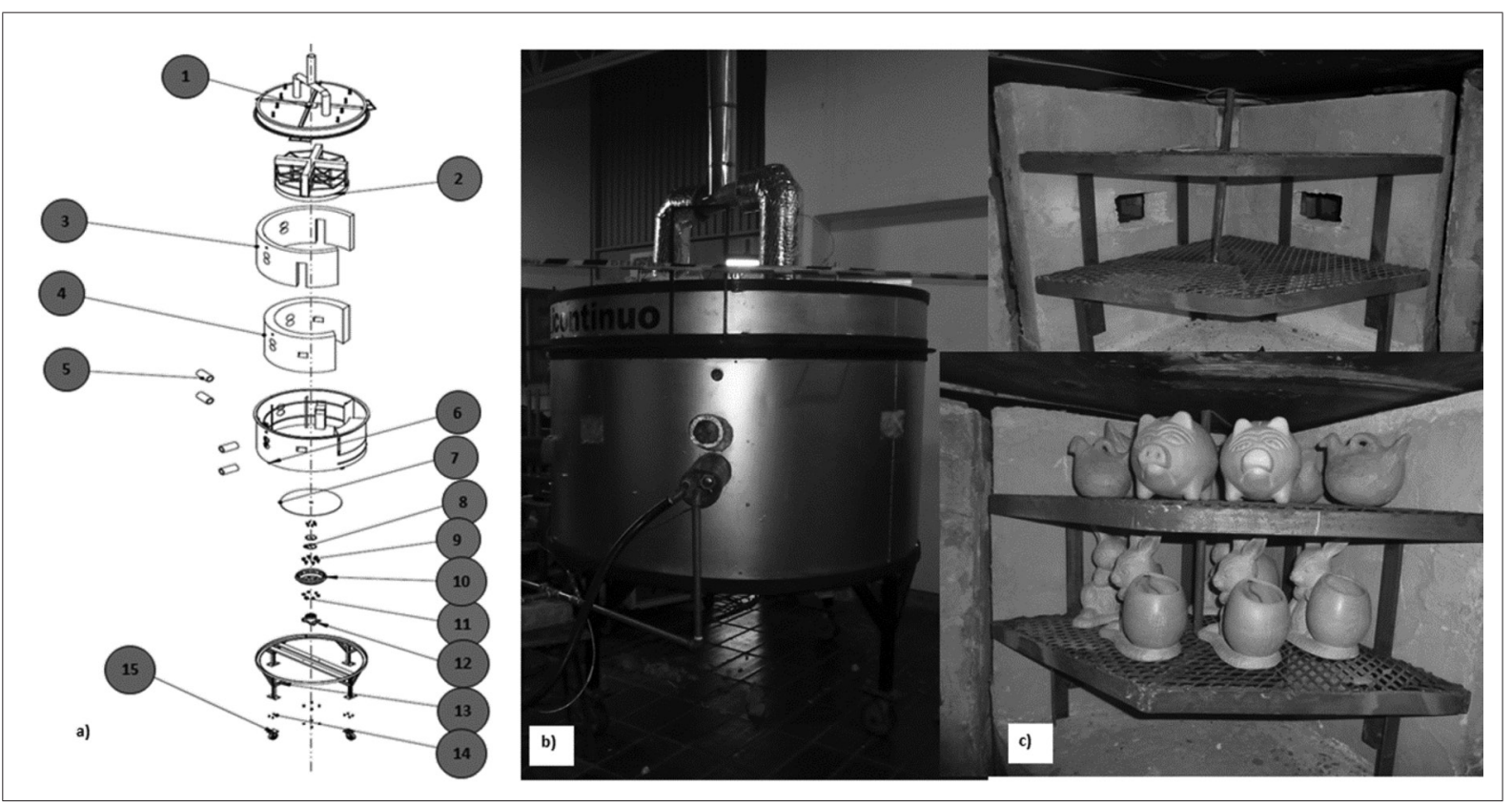

Figure 1. Schematic layout of the vertical axial rotary kiln (a-b) and inner chambers for pottery samples (c) Source: Own work. 
cident. The oxidizer was air; it was fed into the kiln by using a compressor. The inlet pressure was regulated with a control system; however, the outlet pressure was set at $30 \mathrm{kPa}$. A proportional valve changed the air flow rate according to an electrical signal and the volumetric rate was recorded by an air flow meter. A schematic of the experimental setup is presented in figure 2 .

The inner temperatures at each stage (TR1, TR2, TR3, TR4), the ambient and the outlet flue gas temperature (TR5) were sensed using K-type thermocouples and recorded each minute. Moreover, a surface K-type thermocouple was employed to measure the temperature of the external surface at different places; three measurements were performed at different positions of the cover, the external vertical wall and the base. The flue gas composition was monitored using a Bacharach model 300 gas analyzer.
Three tests of seven hours were performed to identify repeatability; three hours were needed for heating the oven until the temperature at sintering stage (TR2) reached $800^{\circ} \mathrm{C}$. Afterwards, the chambers rotated clockwise; hence, the ceramic samples moved to the following stage as illustrated in figure 3. Two hours later, the compartments spun once more, and a new cycle began. That process was followed twice.

\section{Energy efficiency evaluation}

The energy efficiency was evaluated in accordance with Carvalho et al (2013) and Sogut, Oktayand Karakoc (2010). We used an indirect method by measuring the different heat losses. The thermal energy spent by the system was calculated with the propane lower heating value, according to equation (1). Where, $E_{\text {in }}(\mathrm{kJ})$ is the energy load

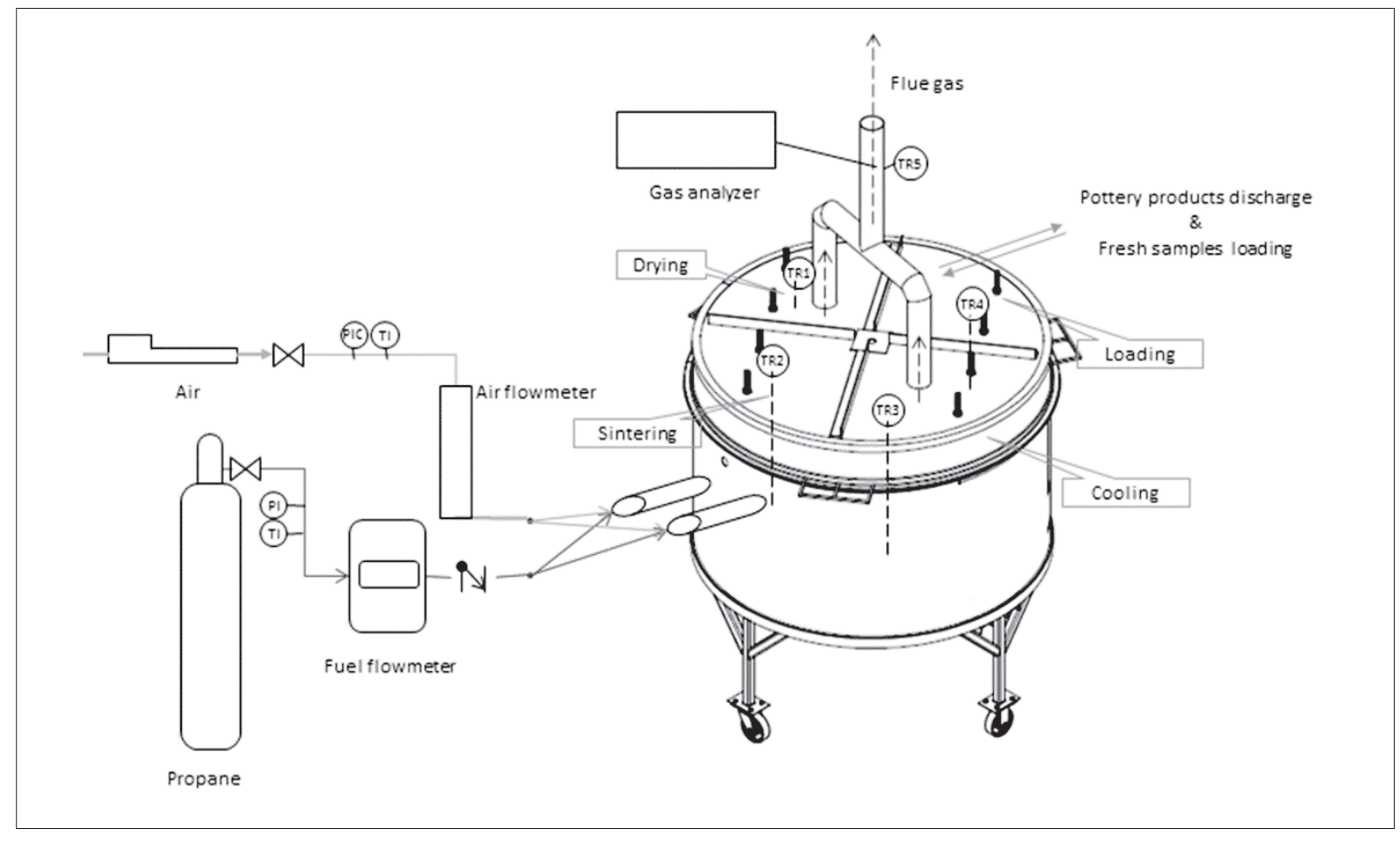

Figure 2. Schematic diagram of the experimental setup

Source: Own work. 
per cycle; $\dot{m}_{\text {fuel }}(\mathrm{kg} / \mathrm{s})$ is the average fuel mass flow rate; $L H V_{\text {fuel }}(\mathrm{KJ} / \mathrm{kg})$ is the fuel heating value, and $d t$ (s) is the time. The parameters needed for this calculation are in table 1.

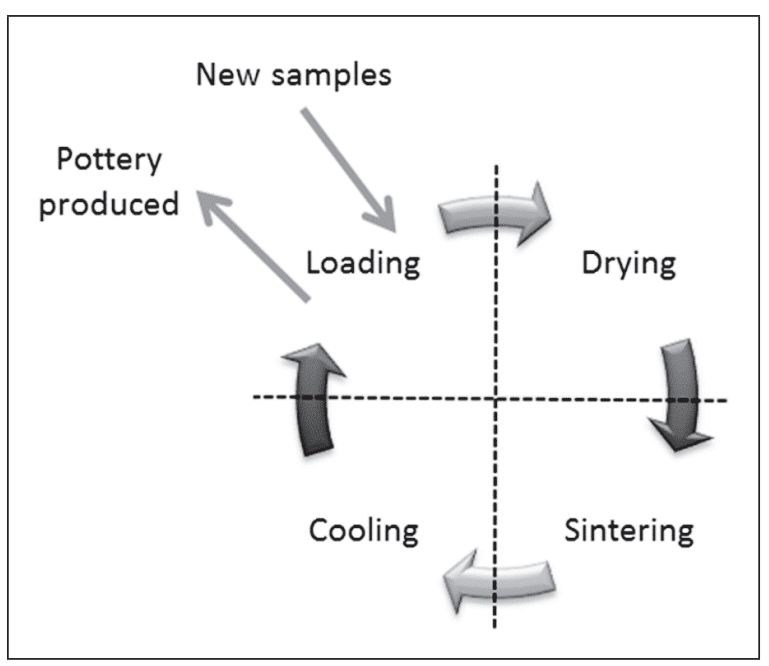

Figure 3. Path followed by the ceramic samples in the kiln after each rotation

Source: Own work.

$$
E_{\text {in }}=\dot{m}_{\text {fuel }} * L H V_{\text {fuel }} * d t
$$

In accordance with equation (2), the outlet energy was equal to the sum of the energy losses due to convection $\left(E_{c}\right)$, radiation $\left(E_{r}\right)$ and the en- ergy losses in the flue gases $\left(E_{f g}\right)$. The convection and radiation heat losses changed with time; they varied depending upon the temperature of each stage. Therefore, the surface temperatures at different sections were monitored.

$$
\begin{gathered}
E_{\text {out }}=E_{c}+E_{r}+E_{f g} \\
E_{c}=E_{c_{\text {loading }}}+E_{c_{\text {drping }}}+E_{c_{\text {sintering }}}+E_{c_{\text {cooling }}} \\
E_{r}=E_{r_{\text {loading }}}+E_{r_{\text {drying }}}+E_{r_{\text {sintering }}}+E_{r_{\text {cooling }}}
\end{gathered}
$$

The convection heat losses $\left(E_{c}\right)$ were evaluated by equation (3); where $E_{c_{\text {looding }}}(\mathrm{kJ}), E_{c_{\text {drying }}}(\mathrm{kJ}), E_{c_{\text {sintering }}}$ $(\mathrm{kJ})$ and $E_{c_{\text {cooling }}}(\mathrm{kJ})$ were the convection heat losses from the chambers located at the loading, drying, sintering and cooling stages, respectively. In the same manner, the radiation heat losses were evaluated independently for each stage by equation (4). Here, three main components constituted the losses of each stage; thus, either convection $\left(E_{c_{y}}\right)$ or radiation heat losses $\left(E_{r_{y}}\right)$ at stage $y$ were the sum of the heat transferred from the wall, the cover and the base to the ambient in accordance with equations (5) and (6).

$$
\begin{aligned}
& E_{c_{y}}=E_{c_{y_{\text {base }}}}+E_{c_{y_{\text {wall }}}}+E_{c_{y_{\text {cover }}}} \\
& E_{r_{y}}=E_{r_{y_{\text {base }}}}+E_{r_{y_{\text {wall }}}}+E_{r_{y_{\text {cover }}}}
\end{aligned}
$$

Table 1. Parameters used during convection and radiation heat losses calculation

\begin{tabular}{|l|l|c|}
\hline \multicolumn{1}{|c|}{ Parameter } & \multicolumn{1}{c|}{ Symbol } & Value \\
\hline Area of the cover $\left(\mathrm{m}^{2}\right)$ & $\mathrm{A}_{\text {cover }}$ & 0.4418 \\
\hline Area of the external wall $\left(\mathrm{m}^{2}\right)$ & $\mathrm{A}_{\text {wall }}$ & 3.1526 \\
\hline Area of the base $\left(\mathrm{m}^{2}\right)$ & $\mathrm{A}_{\text {base }}$ & 0.4418 \\
\hline Convection heat transfer coefficient cover $\left(\mathrm{W} \mathrm{m}^{-2}{ }^{\circ} \mathrm{C}^{-1}\right)$ & $\mathrm{h}_{\text {cover }}$ & 5.30 \\
\hline Convection heat transfer coefficient wall $\left(\mathrm{W} \mathrm{m}^{-2}{ }^{\circ} \mathrm{C}^{-1}\right)$ & $\mathrm{h}_{\text {wall }}$ & 5.95 \\
\hline Convection heat transfer coefficient base $\left(\mathrm{W} \mathrm{m}^{-2}{ }^{\circ} \mathrm{C}^{-1}\right)$ & $\mathrm{h}_{\text {base }}$ & 2.97 \\
\hline Aluminum emissivity & $\varepsilon$ & 0.09 \\
\hline Stefan's constant $\left(\mathrm{W} \mathrm{m} \mathrm{m}^{-2} \mathrm{~K}^{-4}\right)$ & $\sigma$ & $5.67^{*} 10^{-8}$ \\
\hline
\end{tabular}

Source: Own work. 
Convection heat losses depended upon the heat transfer coefficient $\left(h_{x}\right)$, the cross sectional area $\left(A_{x}\right)$ and the instantaneous temperature difference between the surface and the ambient $\left(T_{i_{x}}-T_{a m b}\right)$. The latter variable changed with time; therefore, overall convection heat losses were calculated using equation (7) on a dynamic state. Hence, $x$ meant the position where the measure was made (base, wall or cover) and $y$ was the corresponding stage (loading, drying, sintering or cooling).

$$
E_{c_{y_{x}}}=h_{x} * A_{x} * \int_{0}^{t} \frac{d\left(T_{i_{y_{x}}}-T_{a m b}\right)}{d t}
$$

Meanwhile, the radiation heat losses also varied according to the position. The losses at a specific place were calculated using equation (8). $E_{r_{v_{x}}}(\mathrm{~kJ})$ was the radiation heat at the stage $y$ and the section $x$ (base, wall or cover). According to equation (9), $\varepsilon$ was the emissivity of Aluminum, $A_{x}\left(\mathrm{~m}^{2}\right)$ was the area of the section, and $\sigma\left(\mathrm{W} \mathrm{m}^{-2} \mathrm{~K}^{-4}\right)$ was the Stefan-Boltzmann constant. The parameters employed for determining convection and radiation heat losses are presented above in table 1 .

$$
E_{r_{y_{x}}}=\varepsilon^{*} \sigma^{*} A_{x} * \int_{0}^{t} \frac{d\left(T_{i_{y_{x}}}{ }^{4}-T_{a m b}{ }^{4}\right)}{d t}
$$

The energy losses in the flue gases $\left(E_{f_{g}}\right)$ were evaluated using an empirical correlation for combustion systems and the inlet energy in accordance with equations (9) and (10). Here, $F T\left({ }^{\circ} \mathrm{C}\right)$ was the flue gas temperature, $A T\left({ }^{\circ} \mathrm{C}\right)$ represented the ambient temperature, $A_{2}$ and $B$ were factors dependent upon the fuel, and $\mathrm{O}_{2}(\%)$ was the Oxygen measured by the gas analyzer. Consequently, the energy efficiency was defined based on the ratio between the sum of the heat losses and the energy supplied as indicated by equation (11).

$$
\begin{gathered}
E_{f_{g}}=\frac{\left(q A * E_{\text {in }}\right)}{100} \\
q A=(F T-A T) * \frac{\left(A_{2}\right)}{21-O_{2}} \\
\eta=\left(1-\frac{\left(E_{\text {out }}\right)}{E_{\text {in }}}\right) * 100
\end{gathered}
$$

\section{RESULTS AND DISCUSSIONS}

\section{Average air-fuel ratio and energy consumption}

Three tests were performed in order to establish the reliability of the oven when the set-point at the sintering stage was $800^{\circ} \mathrm{C}$. The first stage of the test spent 160 minutes while the internal temperature at sintering stage reached the desired temperature (heating stage). Afterwards, the chambers rotated clockwise; thus, the samples placed at drying moved to the sintering stage, where they remained 120 minutes (steady cycle 1). Finally, we completed the process and moved the samples to the cooling stage for 120 minutes (steady cycle 2).

The fuel consumed to heat the oven was $45 \%$ higher than the fuel required for the oven operation on each steady cycle. The fuel spent during the heating stage was $1.45 \mathrm{~m}^{3}$ while the fuel needed for each cycle was $1 \mathrm{~m}^{3}$. In the first step, the oven employed the energy to warm the walls and heat them up. We monitored the air fuel ratio and the equivalence ratio throughout the tests; the results of average parameters are presented in table 2. The low air rate improved the energy efficiency because there was no heat wasted on warming the excess air stream. Meanwhile, table 2 


\section{investigación}

Table 2. Average air fuel ratio and consumption

\begin{tabular}{|l|c|c|c|c|c|}
\hline & $\begin{array}{c}\text { Fuel rate } \\
\left(\mathbf{m}^{3} \mathbf{h}^{-1}\right)\end{array}$ & $\begin{array}{c}\text { Air rate } \\
\left(\mathbf{m}^{\mathbf{3}} \mathbf{h} \mathbf{- 1}\right)\end{array}$ & A/F ratio & Eq Ratio & $\begin{array}{c}\text { Energy load } \\
(\mathbf{M J})\end{array}$ \\
\hline Preheating & 0.51 & 16.34 & 20.125 & 1.298 & 128.5 \\
\hline Steady State 1 & 0.50 & 15.55 & 19.622 & 1.266 & 88.5 \\
\hline Steady State 2 & 0.46 & 12.81 & 17.547 & 1.132 & 88.4 \\
\hline
\end{tabular}

Source: Own work.

shows the energy supplied to the system. It was calculated assuming the propane heating value as $46.35 \mathrm{MJkg}^{-1}$. While the oven gained energy and the inner temperature increased, the energy load decreased. In fact, a reduction of $30 \%$ could be reached after completing the preheating stage.

\section{Thermal behavior}

The figure 4 shows the average temperature inside each chamber for the different stages during the process. Throughout the tests, the highest temperature was in the sintering stage; also the time spent on reaching the set point was 170 minutes, and the heating rate was $3.98{ }^{\circ} \mathrm{Cmin}^{-1}$. As we mentioned before, the chambers rotated clockwise after reaching this temperature; thus, the samples located on the drying stage moved to the sintering stage. Meanwhile, the chamber at the sintering stage went to cooling. This rotation changed the temperatures inside each stage; the sintering mean temperature decreased from $800^{\circ} \mathrm{C}$ to $541^{\circ} \mathrm{C}$, in the cooling stage the temperature increased $160^{\circ} \mathrm{C}$ whereas for the loading and drying stage the thermal gradient was less than $100^{\circ} \mathrm{C}$. During the first steady cycle, we controlled the fuel and air mass rate based on the sintering temperature; the main objective was to maintain that parameter as constants as possible. That cycle last two hours, from minute 170 to 290 , with a heating rate about $6.52{ }^{\circ} \mathrm{Cmin}^{-1}$. The chamber in the sintering stage reached the set point again and established a new thermal equilibrium condition after 50 minutes.
Throughout this state, the average temperatures in each stage were $135.4^{\circ} \mathrm{C}$ at loading chamber, $143.55^{\circ} \mathrm{C}$ drying, $813.35^{\circ} \mathrm{C}$ sintering, and $289^{\circ} \mathrm{C}$ cooling; these values were adequate because in that way the ceramic samples were not exposed to high thermal gradients resulting on stronger and more resistant pottery products.

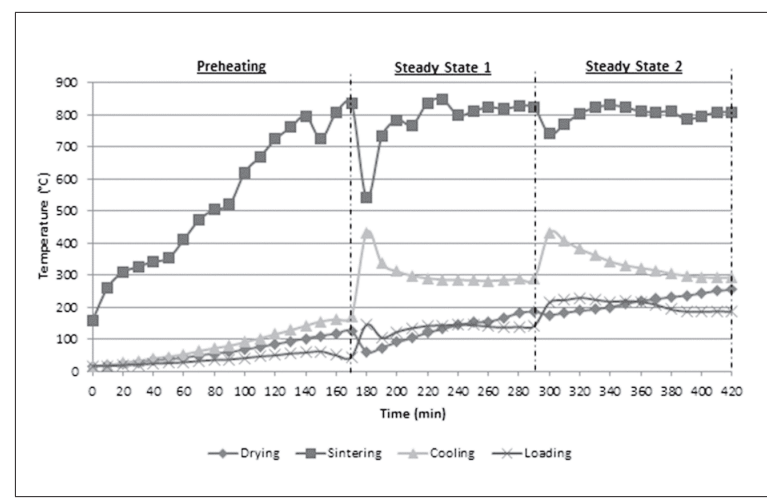

Figure 4. Temperature profile of each stage during the process

Source: Own work.

The chambers spun again after minute 290; the samples placed in the sintering stage went to cooling, and the dry samples moved to sintering. Hence, another cycle began, and the mean temperatures on each stage changed again; the temperature of the sintering stage decreased to $740^{\circ} \mathrm{C}$, and the cooling stage received the sintered samples increasing the mean temperature to $430^{\circ} \mathrm{C}$ instantaneously. Meanwhile, the temperature differences at the drying and loading stages changed less than $100^{\circ} \mathrm{C}$. In this state, the design 


\section{investigación}

of the kiln proofed to need less time before stabilizing. The heating rate went down to $3.2^{\circ} \mathrm{C} \mathrm{min}^{-}$ ${ }^{1}$, and the oven reached the thermal equilibrium after 20 minutes. The mean temperatures of the loading, drying, sintering and cooling stage were $204^{\circ} \mathrm{C}, 223^{\circ} \mathrm{C}, 809^{\circ} \mathrm{C}$ and $321^{\circ} \mathrm{C}$ respectively.

\section{Convection and radiation heat losses}

The radiation and convection heat losses pointed out how much energy the kiln transferred from the external surfaces to the ambient. The temperature profile at the cover and the base surface were similar, meaning a similar distribution of the heat fluxes in the vertical direction. Figures 5 and 6 present the variation of the external surface temperature at the cover and the vertical wall of the oven during the tests. The average ambient temperature at the test was $20^{\circ} \mathrm{C}$.

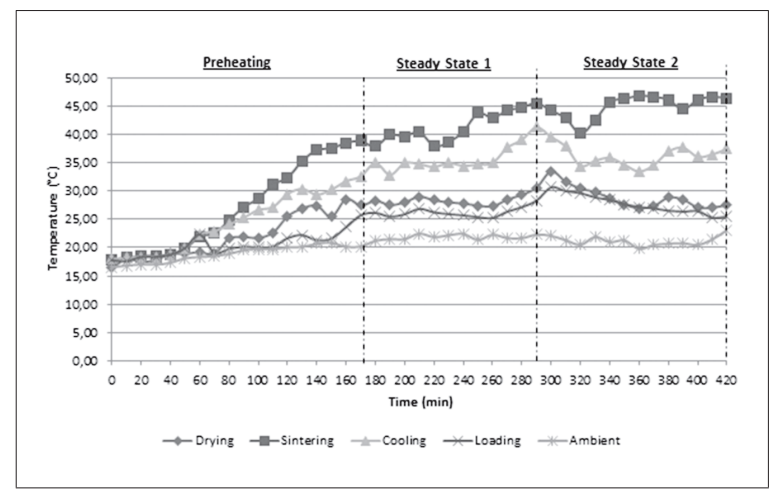

Figure 5. Temperature profile of the kiln cover surface at the different stages of the system

Source: Own work.

The heat flux was higher in the axial direction, and the external wall surface temperature was always greater than the temperatures at the cover and base for all stages. The behavior of the external temperatures was similar to that presented in figure 4; after each rotation, the temperatures of the different stages changed, but the equipment reached the thermal equilibrium soon. Table 3 summarizes the average temperatures at the surface of the cover, the wall and inside each stage during the steady states. Regarding the insulation of the equipment, these values demonstrate an adequate reduction of the temperatures. Comparing the mean temperature inside the chamber with that of the respective external surface indicated the effectiveness of insulation. Temperatures reduction varied between 80 to $95 \%$, while in the sintering stage, the temperature decreased more than $90 \%$. The chambers had the same thermal distribution; the differences between the temperature at the wall and the cover were almost the same, $9^{\circ} \mathrm{C}$ was the highest difference recorded; thus, thermal homogeneity at each stage can be assumed for further analysis.

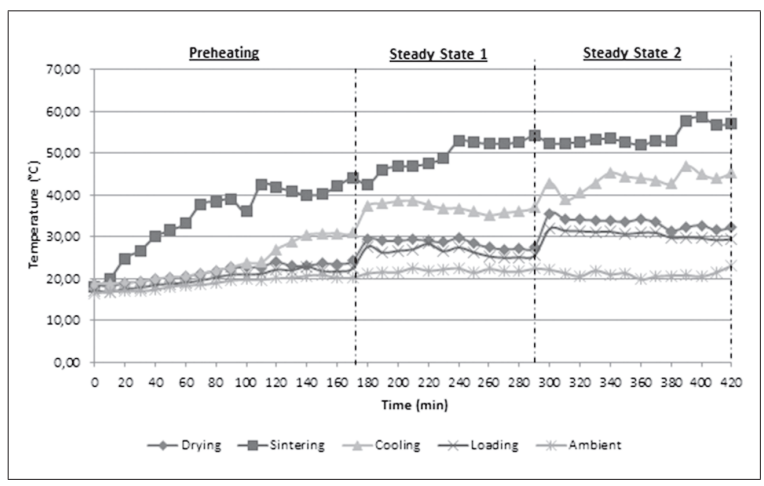

Figure 6. Temperature profile of the external wall surface at each stage

Source: Own work.

The convection and radiation heat losses increased after each rotation due to the higher temperature difference between the surfaces and the ambient. Table 4 summarizes the energy losses; the heat, wasted at sintering stage, shared between 43 to $62 \%$ of the total convection losses and meant about 45 to $60 \%$ of the overall radiation losses. More work should focus on reducing the energy fluxes from the sintering stage surfaces to the ambient. Therefore, the addition of more insulation between the chambers and the external wall or the use of materials with a lower thermal conductivity constant, are attractive alternatives. 


\section{investigación}

Table 3. Mean value and standard deviation of the temperatures recorded inside and at the external surfaces of each stage during the steady states.

\begin{tabular}{|l|c|c|c|c|c|c|c|c|c|c|c|c|}
\hline \multirow{2}{*}{ Location } & \multicolumn{4}{|c|}{ Steady state 1 } & \multicolumn{4}{c|}{ Steady state 2 } \\
\cline { 2 - 15 } & \multicolumn{2}{|c|}{ Inside } & \multicolumn{2}{c|}{ Cover \& Base } & \multicolumn{2}{c|}{ Wall } & \multicolumn{2}{c|}{ Inside } & \multicolumn{2}{c|}{ Cover \& Base } & \multicolumn{2}{c|}{ Wall } \\
\hline Stage & $\bar{x}$ & $\sigma$ & $\bar{x}$ & $\sigma$ & $\bar{x}$ & $\sigma$ & $\bar{x}$ & $\sigma$ & $\bar{x}$ & $\Sigma$ & $\bar{x}$ & $\sigma$ \\
\hline Loading & 135.46 & 12.51 & 26.22 & 0.92 & 26.32 & 1.09 & 204.84 & 17.15 & 27.36 & 1.32 & 30.47 & 0.77 \\
\hline Drying & 143.55 & 31.52 & 28.47 & 1.00 & 28.33 & 0.97 & 223.17 & 22.65 & 28.27 & 1.23 & 33.09 & 1.02 \\
\hline Sintering & 813.35 & 24.12 & 41.90 & 2.72 & 50.66 & 2.82 & 809.39 & 12.62 & 45.22 & 2.19 & 54.27 & 2.43 \\
\hline Cooling & 289.62 & 8.862 & 36.14 & 2.39 & 36.83 & 1.16 & 321.22 & 30.08 & 35.59 & 1.29 & 43,88 & 1,73 \\
\hline
\end{tabular}

Source: Own work.

Table 4. Convection and radiation heat losses

\begin{tabular}{|l|c|c|c|c|c|c|}
\hline \multirow{2}{*}{} & \multicolumn{3}{|c|}{ Convection heat losses (MJ) } & \multicolumn{3}{c|}{ Radiation heat losses (MJ) } \\
\cline { 2 - 7 } & Preheating & Steady state 1 & Steady state 2 & Preheating & Steady state 1 & Steady state 2 \\
\hline Loading (MJ) & 0.296 & 0.727 & 1.564 & 0.028 & 0.070 & 0.150 \\
\hline Drying (MJ) & 0.645 & 1.060 & 1.998 & 0.061 & 0.103 & 0.194 \\
\hline Sintering (MJ) & 3.539 & 4.257 & 5.514 & 0.306 & 0.425 & 0.591 \\
\hline Cooling (MJ) & 1.205 & 2.401 & 2.702 & 0.117 & 0.243 & 0.379 \\
\hline Total (MJ) & 5.685 & 8.445 & 11.778 & 0.512 & 0.841 & 1.314 \\
\hline
\end{tabular}

Source: Own work.

\section{Flue gases heat losses}

A valuable advantage of this innovative kiln was the use of gaseous fuels instead of solid fuels. Several small and medium-scale ceramic industries in Colombia employ coal at their furnaces despite the low energy efficiency, the high air fuel ratios and the high flue gas heat losses. The low equivalence ratio $(<1.3)$ had a direct relationship on the flue gas composition and the heat losses. The flue gas mean composition changed during each rotation due to the temperature variation at each chamber. The Oxygen content was $14.37 \%, 12.51 \%$ and $11.65 \%$, the $\mathrm{CO}$ emissions varied, from 33 to $93 \mathrm{ppm}$, and the $\mathrm{CO}_{2}$ moved from $4.2 \%$ to $7.5 \%$. We mentioned above that flue gas losses depended upon the Oxygen content and the temperature; as defined by empirical equations established to calculate heat losses based on these parameters. The design of the kiln had not neither flue gas heat recovery nor air preheating systems; therefore, the temperature of the flue gases was about $250^{\circ} \mathrm{C}$, but, due to lower Oxygen content after each rotation, the heat losses fell down from $21.34 \%$ to $18.18 \%$.After the preheating state, the flue gas losses were $27.42 \mathrm{MJ}$, $38 \%$ higher than the losses at steady cycles 1 and 2, 17.01 and 16.07 MJ respectively. One way to reduce these losses is to install a heat exchanger warming up the air supplied.

\section{Energy efficiency evaluation}

The evaluation of the efficiency of this system brought the ratio between the energy needed in the process and the energy supplied. Figure 7 shows the distribution of the energy consumption dur- 


\section{investigación}

ing each state; the convection and radiation heat losses were associated together because the latter meant less than $1.5 \%$ of the energy load. Based on the indirect method, where the efficiency depended on the losses, the efficiency at each state decreased from $73.8 \%$ to $67 \%$ due to the higher convection heat losses. During the preheating stage, the equipment consumed energy to rise the temperature at each chamber until the sintering stage reached the set point; therefore, we did not have any production of ceramics. This means that the energy spent at that phase was compulsory, but it was not directly related with the manufacturing process. During the steady states 1 and 2, we sintered the ceramic samples, so the energy consumed in these states was productive. The process in traditional commercial batch systems comprehends the preheating period and a single steady state; so, the energy efficiency becomes the ratio between the productive energy in the steady state and the total energy fed. The efficiency calculated in that way was $28.67 \%$ for this equipment. The main advantage of this design is that we can process more samples without shutting down the equipment; we just have to rotate the chambers, and a new steady cycle begins. After two steady states, the process energy efficiency was $39.76 \%$, higher than that of traditional batch ceramic systems. Assuming a constant thermal

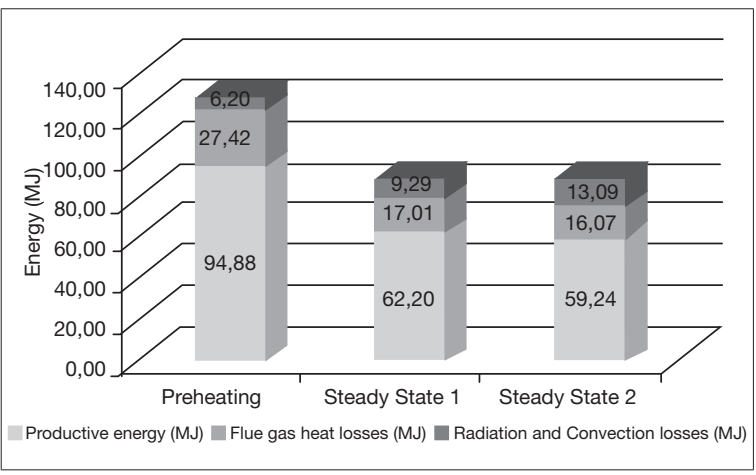

Figure 7. Distribution of the heat losses and the productive energy after each rotation

Source: Own work. behavior as found during the steady states, we can determine that the productive energy efficiency of this equipment becomes was about $60 \%$ after 12 cycles or 24 hours on a continuous mode.

\section{CONCLUSIONS}

The energy efficiency of the designed rotary kiln was evaluated based on the real energy employed for sintering and the total energy supplied. This innovative design demonstrated that a continuous process increased the productive energy efficiency to $60 \%$, in comparison with the typical batch processes, employed in Colombia, where this parameter was around $35 \%$. In this manner, the small and medium scale industries could become more competitive based on the reduction of heat losses during preheating and the decrease of the fuel consumption.

The design of this kiln proven to be stable whereas constant temperatures at each stage were reached faster after each rotation; furthermore, the share of convection and radiation heat losses decreased. Thus, this design could be implemented to replace the traditional systems based on coal combustion, which have higher heat losses, and do not let continuous ceramic processing. The use of gaseous fuel instead of coal mitigates the emission of greenhouse gases preventing health diseases due to particulate matter and pollutants such as $\mathrm{CO}_{2}, \mathrm{SO}_{x}$ or $\mathrm{NO}_{\mathrm{x}}$. In order to boost the efficiency of this design a recovery heat exchanger should be installed in the flue gas outlet; so, the air could be preheated and the temperature of the gases reduced. These results suggest the feasibility of a rotary kiln for pottery production with lower emissions and higher energy efficiencies. The use of this kiln with an air preheating system during longer periods merit further study; meanwhile, the analysis of the behavior of the system fuelled with other gaseous fuels, such as biogas or syngas resulting of biomass and coal gasification, is remarkable. 


\section{investigación}

\section{ACKNOWLEDGMENTS}

The authors acknowledge financial support of Colciencias by the project code 1101-521-29311, and the technical support of the staff of the Clean Development Mechanisms and Energy Management Research Group.

\section{REFERENCES}

Artesanias de Colombia S.A. (2008). Proyecto de mejoramiento en la calidad y certificación de productos de artesanos en 13 comunidades ubicadas en los departamentos del Atlántico, Antioquia, Boyacá, Caldas, Cauca, Chocó, Santander, Sucre y Valle del Cauca. Bogotá, Colombia.

Carvalho, L., Wopienka, E., Lundgren, J., Kumar, V. K., Haslinger, W., et al. (2013). Performance of a Pellet Boiler Fired with Agricultural Fuel. Applied Energy, 104, 286296.

Cheng, J., Zhou, J., Liu, J., Zhou, Z., Huang, Z., Cao, X., et al. (2003). Silfur Removal at High Temperature during Coal Combustion in Furnaces: A Review. Progress in Energy and Combustion Science, 29, 381-405.

Concejo Municipal de Ráquira (2012). Acuerdo por medio del cual se adopta el plan de desarrollo del municipio de Ráquira Boyacá "Porque Ráquira somos todos". Acto 006. Ráquira, Colombia.

Ginsberg, T., \& Modigell, M. (2011). Dynamic Modeling of a Rotary Kiln for Calcination of Titanium Dioxide White Pigment. Computer \& Chemical Engineering, 35, 24372446.

International Energy Agency (IEA) (2011). CO2 Emissions from Fuel Combustion.París: International Energy Agency.
International Energy Agency (IEA) (2012). Key World Energy Statistcis. Retrieved from www.iea.org

Jones, J., Bridgeman, T., Darvell, L., Grudka, B., Saddawi, A., \& Williams, A. (2012). Combustion Properties of Torrefied Willow compared with Bitominous Coals. Fuel Processing Technology, 101, 1-9.

Marias, F. (2003). A Model of a Rotary Kiln IncineratorIncluding Processes Occurring Within the Solid and the Gaseous Phases. Computers \& Chemical Engineering, 27, 813-825.

Matau, F., Nica, V., Postolache, P., Ursachi, I., Cortiug, V., \& Stancu, A. (2013). Physical study of the Cucuteni Pottery Technology. Journal of Archaeological Science, 40, 914-925.

Matheus, J., Miller, B., Song, C., Schobert, H., Botha, F., \& Finkleman, R. (2013). The EBB and Flow of US Coal Research 19702010 with a Focus on Academic Institutions. Fuel, 105, 1-12.

Olajire, A. (2010). CO2 Capture and Separation Technologies for end-of-Pipe Applications - A review. Energy, 35, 2610-2628.

Rasmussen, K., De la Fuente, G., Bond, A., Mathiesen, K., \& Vera, S. (2012). Pottery Firing Temperatures: A New Method for 


\section{investigación}

Determining the Firing Temperature of Ceramics and Burnt Clay. Journal of Archaeological Science, 39, 1705-1716.

Saidur, R., Hossain, M., Islam, M., Fayaz, H., \& Mohammed, H. (2011). A Review on Kiiln System Modeling.Renewable and Sustainable Energy Reviews, 15, 2487-2500.

Sinning Durán, A. (2010). Relaciones ecológicas urbano-rurales en el municipio de Ráquira (Boyacá) (tesis maestría). Pontificia Universidad Javeriana, Bogotá, Colombia.

Sogut, Z., Oktay, Z., \& Karakoc, H. (2010). Mathematical Modeling of Heat Recovery from a Rotary Kiln. Applied Thermal Engineering, 30, 817-825.

Trindade, M., Dias, M., Rocha, F., Prudencio, M., \& Coroado, J. (2011). Bromine Volatilization during Firing of Calcareous and NonCalcareous Clays: Archerometric Implications. Applied Clay Science, 53, 489-496.

UPME (2012). Cadena del carbón. Bogotá: UPME.

Zhang, J., Zhou, Z., Ma, L., Li, Z., \& Ni, W. (2013). Efficiency of Wet Feed IGCC (Integrated Gasification Combined Cycle) Systems with Coal-Water Slurry Preheatng Vaporization Technology. Energy, 51, 137-145. 